\title{
Studies on the Serum Insulin in Diabetics by Three Methods
}

\section{Taiso SHINDO}

\author{
The 1st Department of Internal Medicine, Kyoto Prefectural University of Medicine, \\ Kyoto, Japan (Director : Professor Hideo Yoshida, M.D.)
}

Several methods have been used for the assay of insulin in human serum. The bioassay methods most commonly used utilize the insulin sensitivity of the gulcose uptake by isolated rat diaphragm, or the oxidation of glucose by the isolated rat epididymal fat pad. More recently, immunochemical techniques have been widely used, which depend on competition between serum insulin and $\mathrm{I}^{131}$-insulin for a limited amount of guinea-pig antiinsulin antibody. There are considerable differences in the results between bioassay and radioimmunoassay. Furthermore, these results have different significances. Pathogenesis of diabetes mellitus was studied by determination of serum insulin concentration in normal and untreated diabetic subjects before and after glucose loading. Serum insulin concentrations were determined using the rat diaphragm assay (DILA), the rat epididymal fat pad assay (FILA) and the radioimmunoassay technique (IRI) for the same serum samples and at the same time. Twenty-three subjects with no known diabetic heredity served as controls. All of them had normal glucose tolerance. Forth-five patients with diabetes mellitus except Kimmelsties-Wilson's syndrome had never received insulin or oral hypoglycemic agents. They were classified according to fasting blood sugar levels as either severe diabetic group with that above $200 \mathrm{mg} / \mathrm{dl}$ or mild diabetic group with that below 199 $\mathrm{mg} / \mathrm{dl}$. Ten chemical diabetics were contained in mild diabetic group. Mean fasting levels of DILA, FILA and IRI in normal subjects were $310 \pm 50 \mu \mathrm{u} / \mathrm{ml}, 399 \pm 148 \mu \mathrm{u} / \mathrm{ml}$ and $21.3 \pm 7.3 \mu \mathrm{u} / \mathrm{ml}$; in mild diabetic group $203 \pm 74 \mu \mathrm{u} / \mathrm{ml}, 531 \pm 92 \mu \mathrm{u} / \mathrm{ml}$ and $32.8 \pm 9.6$ $\mu \mathrm{u} / \mathrm{ml}$; in severe diabetic group $100 \pm 22 \mu \mathrm{u} / \mathrm{ml}, 276 \pm 45 \mu \mathrm{u} / \mathrm{ml}$ and $9.3 \pm 1.9 \mu \mathrm{u} / \mathrm{ml}$, respectively. These observations indicate that fasting DILA levels are lowered in both diabetic groups, and fasting FILA and IRI levels are elevated in the mild diabetic group. But both FILA and IRI in severe diabetic group were lowered. Blood sugar, DILA, FILA and IRI were measured in serum obtained from normal and diabetic subjects in the fasting state, and thirty, sixty, ninety and one hundred and twenty minutes following $50 \mathrm{~g}$ oral glucose loading. In normal subjects, DILA, FILA and IRI rose briskly, reaching a peak within thirty to sixty minutes, and then declined gradually. Its mean peak levels of DILA, FILA and IRI were $673 \pm 114 \mu \mathrm{u} / \mathrm{ml}, 821 \pm 168 \mu \mathrm{u} / \mathrm{ml}$ and $78.0 \pm 13.2 \mu \mathrm{u} / \mathrm{ml}$, respectively. In the mild diabetic group, the initial FILA was definitely delayed but its concentrations continued to rise for ninety minutes, eventually reaching average levels of FILA considerably higher than that achieved at any time in normal subjects, and the initial IRI was definitely delayed to ninety minutes. The mean peak levels of FILA and IRI were $1402 \pm 166 \mu \mathrm{u} / \mathrm{ml}$ and $79.6 \pm 14.8 \mu \mathrm{u} / \mathrm{ml}$ at ninety minutes after glucose loading. However, peak responses 
of DILA in mild and severe diabetic groups to glucose loading were lowered and that in the severe diabetic group were more delayed than in normal subjects. Peak levels of DILA in mild and severe diabetic groups were $373 \pm 96 \mu \mathrm{u} / \mathrm{ml}$ and $181 \pm 40 \mu \mathrm{u} / \mathrm{ml}$ respectively. Peak responses of FILA and IRI in the severe diabetic group were more lowered and more delayed than in normal subjects. Mean peak levels of FILA and IRI in the severe diabetic group were $371 \pm 242 \mu \mathrm{u} / \mathrm{ml}$ and $17.7 \pm 8.0 \mu \mathrm{u} / \mathrm{ml}$ at ninety minutes after glucose loading.

The pattern of insulin response of chemical diabetes was very similar to that of the mild diabetic group. The observation shows diminished insulin effect to muscle tissues and suggests the possibility that the serum of mild diabetic subjects contains a large amount of ineffective insulin to muscle tissue but of effective insulin to fat tissue.

Therefore, the possibility that DILA inhibitor and FILA activator in mild diabetic subjects were the meaningful factors was suggested.

It was suggested that pancreatic insulin stores were decreased in severe diabetic subjects and that severe diabetic subjects might secrete less insulin shortly after glucose loading than normal subjects. Mean fasting levels of DILA, FJLA and IRI in mild cases of juvenile diabetic subjects were $180 \pm 123 \mu \mathrm{u} / \mathrm{ml}, 590 \pm 68 \mu \mathrm{u} / \mathrm{ml}$ and $37.0 \pm 2.6 \mu \mathrm{u} / \mathrm{ml}$, and those of DILA, FILA and IRI in severe cases of them were $93 \pm 7 \mu \mathrm{u} / 7 \mu \mathrm{u} / \mathrm{ml}, 275 \pm 22 \mu \mathrm{u} / \mathrm{ml}$ and $9.5 \pm 1.7 \mu \mathrm{u} / \mathrm{ml}$, respectively.

Peak responses of DILA in mild and severe cases of juvenile diabetic subjects were lowered and those in severe cases only were delayed more than in normal subjects. Mean peak level of DILA in mild cases was $415 \pm 141 \mu \mathrm{u} / \mathrm{ml}$ and that in severe cases was $169 \pm 23$ $\mu \mathrm{u} / \mathrm{ml}$ at ninety minutes after glucose loading. Peak responses of FILA and IRI in mild cases were delayed and those of FILA were elevated. Mean peak levels of FILA and IRI were $1550 \pm 166 \mu \mathrm{u} / \mathrm{ml}$ and $95.0 \pm 9.5 \mu \mathrm{u} / \mathrm{ml}$ at ninety minutes after glucose loading. Peak responses of FILA and IRI in severe cases were lowered and delayed, and the levels of FILA and IRI were $399 \pm 101 \mu \mathrm{u} / \mathrm{ml}$ and $21.0 \pm 6.4 \mu \mathrm{u} / \mathrm{ml}$ at ninety to one hundred and twenty minutes. These findings were obtained in Kimmelstiel-Wilson's syndrome. Therefore, the characteristic pattern of serum insulin response was not obtained in juvenile diabetic subjects and Kimmelstiel-Wilson's syndrome.

(pp. 552 564) 


\title{
三測定法による糖尿病患者の血中 Insulin 動態
}

\author{
京都府立医科大学第一内科学教室（指導: 吉田秀雄教授） \\ 進藤 岱 三 \\ (昭和43年 1 月30日受付)
}

糖尿病の病態を解明する方法として, 今日横隔膜法, 副睪丸脂肪組織法及び免疫学的測定法の 3 つの 湘定方法を用いて同一血清中の insulin を測定する必要がある。そてで，てれら３つの方法を用いて 糖尿病患者の血中 insulin 動態を研究した. ブドー糖負荷前後の ILA 及び IRI は糖尿病の重症度に より特異的な変動を示し，DILA-inhibitor が本症発病に重要な因子であると考光られる.

\section{緒言}

糖尿病は，体内に於ける insulin の絶対的或は相対的欠乏に基因する代謝疾患であると定義されている. 従つて, 血中 insulin の測定が，糖尿病の病態解明の為に極めて重要な意義を持つている，1938年， Hemmingsen $ら^{1)}$ は insulin の血糖下降作用飞基いて，血中 insulin を測定しようとする in vivo bioassay を発表した，乙の方法は，その後 Anderson ${ }^{2)}$ 或いは，Bornstein ${ }^{3)}$ らにより改良されたけれぞも，感度が不 充分である事，手技の煩雑さ，動物の死亡率の高い事等から広く用いられるには至らなかつた。

1940年, Gemmill ${ }^{4)}$ は, ラットの剔出横隔膜のブドー糖摂取能, 或いは, 糖原合成能が in vitro で添加さ れた insulin により著しく促進される事を報告した。 それ以来，多くの研究者が，ての方法を改良して血 中 insulin を測定している(5)677)8 .

1950年 Renold ら ${ }^{9)}$ は，脂肪組織が活発な代謝を営んでいる事に注目し， insulin が in vitro でラット の剔出副睪丸脂肪組織のブドー糖捸取能を著しく充進させるととを確め，乙の事実を利用して血中 insulin を測定した.

更に，現在最も insulin に特異的であると考光られている免疫学的測定法が，1960年，Berson 及び Yalow 10)により報告された。 それ以後, 免疫学的測定法を用いて多くの報告がある.

従つて, 今日用いられている主な血中 insulin の測定法伒, 生物学的測定法, 即ち, ラット剔出横隔膜 法とラット剔出副殬丸脂肪組織法, 及び免度学的測定法の 3 つの方法がある。乙れら 3 つの方法も各々一長 一短があり, 生物学的測定法ではその測定されたものは insulin 樣活性（以下 ILA と略す）という言葉 で表わされている如く, insulin それ自身の作用結果だけではなく，血清又は血漿中に含まれるその他の物 質の有す生物学的効果の集約であると考えなければならない, 一方, 免疫学的測定法についても, 抗原性を 有するが，生物学的には非活性の insulin をも含めて測定されているのではないかという疑問がある ${ }^{11) 122}$. それ故に, 前述の 3 つの方法の内一つ又は 2 つの方法を用いて糖尿病の病態を論ずる事は危険である. 亦, 同時に 1 法又は 2 法による沢山の報告を比較検討する場合にも，研究対象及び同じ測定法であつても，用い る指標が異る為に，糖尿病の研究の大きな障害になつている，免疫学的測定法で測定されたものが，全て生 物学的活性を有するか否かは不明であり, 生物学的測定法によるものが insulin 特異性という点で免疫学 的測定法に比べて少ないてとから insulin そのものの動きを反映しているともいい難い，そてで，ラット剔 出横隔膜法, ラット剔出副锌丸脂肪組織法及び免疫学的測定法の 3 つの方法により, 同一症例について, 同 時に血中 insulin を測定する事が，糖尿病の病態解明への近道であり，亦，ぜひ必要である。

著者は, glucose uptake を指標としたラット剔出横隔膜法 ${ }^{576)}$, Glucose-1 $1{ }^{14} \mathrm{C}$ から ${ }^{14} \mathrm{CO}_{2}$ 産生を指標と したラット剔出副睪丸脂肪組織法 ${ }^{13) 14115)}$, 及び dextran-coated charcoal を用いた免废学的測定法 ${ }^{16) 17}$, の3つの血中 insulin 測定法で同一血清を同時に測定して, 血中 insulin の面より桾尿病の病態を解明し ようと試みた。 


\section{対象及び試験方法}

1. 対象

\section{A) 正常対象群}

正常対象群としては, 当内科入院中の糖尿病の遗伝的素因のない, Broca's index $\pm 10 \%$ 以内のブドー糖 負荷試験正常の年令15才から66才の男10例, 女13例, 計 23 例を選んだ.

\section{B）糖尿病患者群}

ブド一糖負荷試験で糖尿病と診断された, 未治療の主として入院中の患者で, 年令 16 才から 68 才迄の男 30 例, 女20例, 計 50 例を選んだ. 本群の年令構成と正常対象群のそれとは殆んど同じであつた。 てれら50例を 空腹時血糖值に基いて軽症群と重症群に分け, 発病年令より若年性糖尿病患者群について, 亦, 特殊な病型 として Kimmelstiel-Wilson, 症候群についても観察した.

\section{i) 軽症群}

空腹時血糖值による重症度の判定は, $140 \mathrm{mg} / \mathrm{dl}$ 以下のものを軽症, $199 \mathrm{mg} / \mathrm{dl}$ 以下のものを中等症とす るものが普通の様であるが本研究では, 血中 insulin の変動に主眼を置いた為, 空腹時血糖值 $199 \mathrm{mg} / \mathrm{dl}$ 以下のものを軽症とした。年令は, 19才から65才迄の男19例女14例, 計 33 例であつた。 ての中には, 空腹時 血糖が正常範囲にあり, 臨床症状のない chemical diabetes が, 男 8 例, 女6 例, 計13例含まれている. この他の20例は overt diabetes である.

\section{ii ) 重症群}

空腹時血糖值 $200 \mathrm{mg} / \mathrm{dl}$ 以上のもので, 年令 16 才から 68 才迄の男 6 例, 女 6 例, 計 12 例であつた.

iii) 若年性糖尿病患者群

発病年令 30 才迄のもので, 男 4 例, 女 4 例, 計 8 例であつた. 本群を, 重症度により尔けると, 軽症群及 び重症群共に 4 例宛であつた。

\section{iv) Kimmelstiel-Wilson 症候群}

糖尿病の late stage と考光られる多くの合併症を併発した特殊型の代表として Kimmelstiel-Wilson 症 候群を選んだ. 従つて, 糖㽷病の経過の長いものが多く, 年令も52才から68才迄の 5 例であり全て男であつ た. 䍜病期間20年の 3 例の内 2 例は insulin，1 例は経口抗糖尿病剂にて治を受けており，てれらの症例は, 症状の恵化を見るてとなく，しかも薬剤の影響を最少限に止める様に $2 〜 4$ 日間休薬して試験を行なつた。 薬剤の長期投与の影響は考慮されなければならない, insulin 治療を受けていた 2 例では, 免疫学的測定法 の成績は, 参考に止めた。残り 3 例の罹病期間は, $2 \sim 7$ 年で治療も不允分で, 経口抗糖尿病剤在時々服用 する程度であり, 薬剤の長期投与の影響はといものと考光られる。尚，i）〜 iii）群の中には，本群の 5 例 は含まれていない.

\section{2. 試験方法}

試験前少なくても 3 日間, 梼質 $300 \mathrm{~g}$ の一定の食慨を摂取させ, 各対象群共一晩絶食後, $50 \mathrm{~g}$ ブドー桾経 口単回負荷試験（以下 GTT と略す）を行ない，負荷前，負荷後30分，60分，90分，120分及び180分に肘 静脈より採血して, 血清を分離後直ち亿血糖, insulin 様活性及び免疫学的活性 insulin を測定した。但し, 免度学的測定法では, 放射性同位元素 $\mathrm{I}^{131}$ の半減期が短く, damaged insulin が生ずるため測定可能な期 間が短く，血清を- $20^{\circ} \mathrm{C}$ 亿て凍結保存して測定した場合もある. 亦, 生物学的測定法では, 一回当り測定出

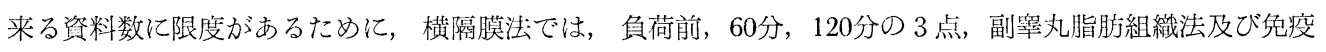
学的測定法では, 負荷前, 30分, 60分, 90分, 120 分の 5 点で測定した。血糖は採血せる 6 点で測定した。

\section{3. 測定方法}

\section{A）ラット剔出横隔膜法}

使用動物は, 室温 $18 \pm 3^{\circ} \mathrm{C}$ の恒温室沉於いて, Oriental 固型飼料を以つて 2 週間以上飼育した体重 $130 \mathrm{~g}$ 前後の Wister 系の雄性ラットを使用した. ラットを15時間絶食後, 断頭屠殺し, 速か亿横隔膜を剔出する. 
これを直ちに $5^{\circ} \mathrm{C}$ 以下に冷却した Gey \& Gey Buffer (pH7.4) に浸した。 横隔膜の使用法は VallanceOwen, ${ }^{5)}$ Cunningham $ら^{6)}$ の hemidiaphragm technique の変法を用いた。横隔膜を 4 等分して, 予め $200 \mathrm{mg} /$ di の glucose を含む Gey \& Gey Buffer $2.0 \mathrm{ml}$ を incubation medium として用意した flask 内に 2 片 づつ入れ，1 ケの flask 中には hemidiaphragm が入る様にした. 立填ガスには95〜100\%の酸素を用いた。 密栓後, $37.5^{\circ} \mathrm{C}$ で90分間 90 回転/分で incubate した. incubation 前後の medium 中の糖濃度を Hagedorn-Jensen 氏法 ${ }^{18)}$ そ依り測定した. medium 中の横隔膜片は incubation 後 Torsion-balance にて科量 した，横隔膜の glucose uptake は, incubation medium 中の糖濃度の減少及び横隔膜の湿重量より奥村 の方法 ${ }^{19)}$ と同じく下記の式を以つて算出した.

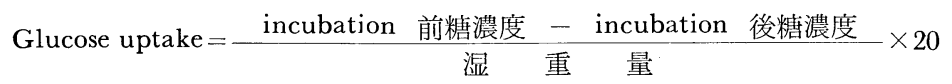

incubation medium そブドー糖加 Gey \& Gey buffer のみを使用した場合の glucose uptake をその横 隔膜の basal uptake とした. ラット 4 匹を一組とする実験で 8 ケの flask の内 2 ケを basal uptake 測 定にあて，他に被検液を夫々添加した場合，後者の glucose uptake より，同日に測定した basal uptake を差引いた值を以つて, 被検液による extra-glucose ( $\Delta$-uptake), 殊にその被検㳔に insulin 溶液を用いた 場合に insulin effect とした。標準 insulin には豚結晶 insulin (Novo 社製) を用い, insulin 濃度と insulin effect は, insulin 濃度 $10^{-2} \sim 10^{-5} \mathrm{u} / \mathrm{ml}$ の範囲で insulin 濃度を片対数グラフにとると直線関係 を示し，その回帰直線は，Yc=0.732X-0.170 で表わされる（Fig. 1). 血清 ILA 測定に際しては， 5 倍 稀釈で行ない，本法により測定された血清 ILA を DILA と略す。

\section{B）ラット剔出副睪丸脂肪組織法}

Renold ら ${ }^{13)}$ ，Pfeiffer $~^{14)}$ 及び富川の方法 ${ }^{15)}$ そ準じて， ラット副睪丸脂肪組織を用い glucose-1- ${ }^{14} \mathrm{C}$ (R.G.C. より購入) から ${ }^{14} \mathrm{CO}_{2}$ への変化を指標とする方法により測定した。即ち，前法と全く同じ条件の ラット 3 匹を断頭放血致死せしめ, 直ちに開腹, 速やかにしかも出来るだけ注意深く左右副睪丸脂肪組織を 摘出し, Krebs-Ringer bicarbonate buffer に浮遊せしめる。15分後，各組織末梢部を 3 分し，合計18ケの 組織片より 3 ケづつ取り，その湿重量を $80 〜 120 \mathrm{mg}$ として， incubation flask に入れ，95\% $\mathrm{O}_{2}-5 \% \mathrm{CO}_{2}$ 混 合ガスにて 2 分間ガス交換し，好気的条件の下で $37.5^{\circ} \mathrm{C}, 90$ 回転/分， 3 時間 incubate する。 incubation 終了後, $1.8 \mathrm{~N}-\mathrm{NaOH} 0.2 \mathrm{ml}$ を center well に注入し, 他方, medium 中には $10 \mathrm{~N}-\mathrm{H}_{2} \mathrm{SO}_{4} 0.2 \mathrm{ml}$ を注入

Fig. 1. Standard regression line of rat diaphragm assay

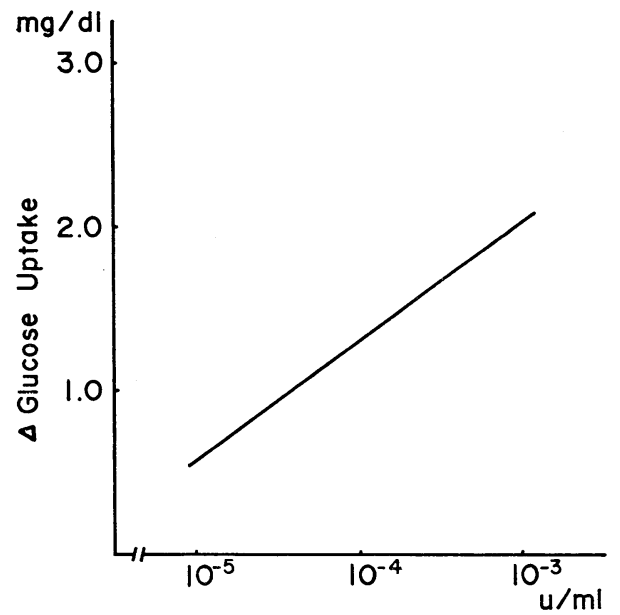

Fig. 2. Standard regression line of rat epididymal fat pad assay

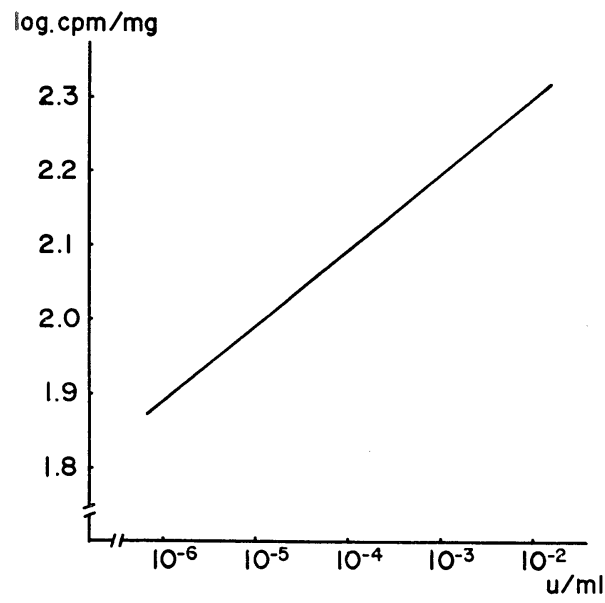


し, 更に同条件で 1 時間 incubate して発せる ${ }^{14} \mathrm{CO}_{2}$ を $\mathrm{NaOH}$ 亿吸着させた。 ${ }^{14} \mathrm{CO}_{2}$ を吸着した $\mathrm{NaOH}$ を $3 \% \mathrm{BaCl}_{2}$ と $2.5 \% \mathrm{NH}_{4} \mathrm{Cl}$ の混合溶没を入れた遠沈管に移し, $\mathrm{Ba}^{14} \mathrm{CO}_{3}$ として gas flow counter でそ の total count を測定し, self-absorption を補正して, counts/min/mg tissue weight を算出した.

incubation medium は, 毎回新調した pH7.4の Krebs-Ringer bicarbonate buffer を使用し, glucose $300 \mathrm{mg} / \mathrm{dl}$, gelatin $200 \mathrm{mg} / \mathrm{dl}$ の濃度に溶解したもの $1.9 \mathrm{ml}$ に D-glucose- $1-{ }^{14} \mathrm{C} 0.2 \mu \mathrm{c}(0.1 \mathrm{ml})$ を加えて $2 \mathrm{ml}$ とした。 insulin 作用濃度直線の作製には豚結晶 insulin (Novo 社製) 用い, insulin 濃度 $10^{-2} \sim 10^{-6} \mathrm{u} / \mathrm{ml}$ の範囲では, insulin 濃度 と ${ }^{14} \mathrm{CO}_{2}$ の $\mathrm{cpm} / \mathrm{mg}$ との両対数の間に, 直線関係を示し, その回帰直線は, $\mathrm{Y}_{\mathrm{c}}=0.1037 \mathrm{X}+2.5066$-゙表わされる. (Fig. 2) 血清測定に際しては， 5 倍稀釈にて測定し，本法に测定され た血清 ILA を FILA と略す。

\section{C) 免疫学的測定法}

豚 insulin をモルモットに皮下注射して抗 insulin 血清（以下 AIS と略す）を作製した。標準 insulin には human insulin (Novo 社製)， ${ }^{131}$-insulin には高比放射能の pork $\mathrm{I}^{131}$-insulin (Dainabbot 社製) を 使用した。 dextran-coated charcoal は dextran 80 及び charcoal (Merk 社製) を pH7.4 の barbital acetate buffer そ溶解して作成した。血清 AIS 及び $\mathbf{I}^{131}$-insulin の稀勫には牛血清 albumin を $5 \%$ の割合で添 加した pH7.4の barbital acetate buffer 者使用した.

之を用いて Herbert ${ }^{16)} の$ dextran-coated charcoal 法の吉田ら ${ }^{17)}$ の変法に従つた. $10 \mu \mathrm{u} / \mathrm{ml}$ の $\mathrm{I}^{131}$-insulin $0.5 \mathrm{ml}, 20,000$ 倍稀釈の AIS $0.5 \mathrm{ml}$ と標準 insulin 又は 2 倍稀橎血清 $1.0 \mathrm{ml}$ を加えて全量 $2 \mathrm{ml}$ とし，乙 れを $4{ }^{\circ} \mathrm{C} て ゙ 4$ 日間 incubate した。 その後 dextrancoated charcoal $3.0 \mathrm{ml}$ を加えて, 直ちに室温で 3000 $\mathrm{rpm}$ で15分間遠沈し，上清の free insulin と沈澱の bound insulin を分離して後, well-type scintillation counter で夫々を count した. \% F $=\frac{\mathrm{F}}{\mathrm{B}+\mathrm{F}} \times 100$ より各標準 insulin 濃度の \% F t求め, \% F 縦軸 に，標準 insulin 濃度を横軸にとり，片対数グラフに plot した. (Fig. 3)

未知血清の $\% \mathrm{~F}$ より毎回作成した標準直線を利用し て, 未知血清の insulin 濃度を求めた。本法により 測定した血中 insulin を IRI と略す。

\section{D) 血清測定法}

Fig. 3. Standard regression line of radioimmunoassay

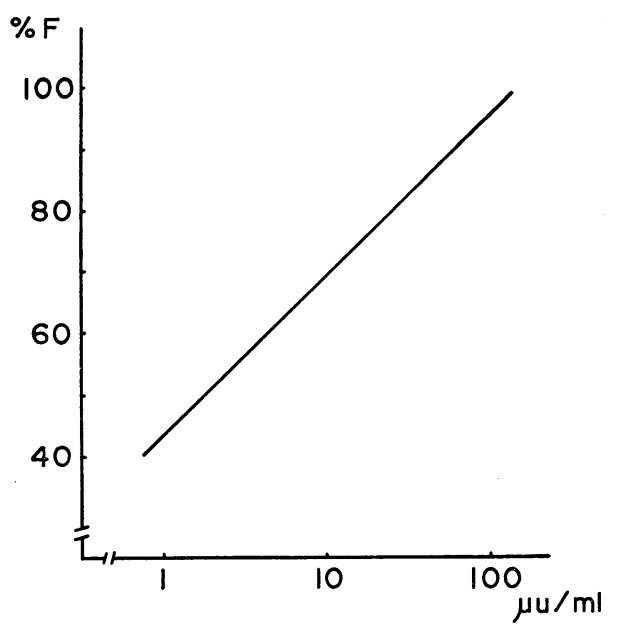

血精測定は, Hagedorn-Jensen 氏法 ${ }^{18)}$ を用いた。

\section{4. 測 定 成 績}

\section{A) 正常対象群}

1）空腹時値

本群23例の空腹時血糖值は 67〜 99mg/dl で, 平均空腹時血糖值は $83 \mathrm{mg} / \mathrm{dl}\left(\mathrm{SD}_{ \pm} 9\right)$ であつた。 (Fig. 5) 空腹時 DILA は 210 $400 \mu \mathrm{u} / \mathrm{ml}$ で，平均空腹時 DILA $310 \mu \mathrm{u} / \mathrm{ml}\left(\mathrm{SD}_{ \pm} 50\right)$ は空腹時 FILA は 200〜 $650 \mu \mathrm{u} / \mathrm{ml}$ で, 平均空腹時 FILA は $399 \mu \mathrm{u} / \mathrm{ml}$ ( $\mathrm{SD} \pm 148)$ であつた. 空腹時 IRI は 16〜28 $\mu \mathrm{u} / \mathrm{ml}$ で, 平均空腹時 IRI は $21.3 \mu \mathrm{u} / \mathrm{ml}\left(\mathrm{SD}_{ \pm}\right.$7.3) であつた。 てれら平均空腹時值を各々の正常値とした。 以上の 如く, 空腹時血清 ILA は血清 IRI より著しい高値を, 更に FILA は DILA より高い值いを示した。 (Fig. 4)

\section{2） GIT 亡血清 insulin 反応}

本群の GTT 時の平均血糖曲線は, Fig. 5 そ示した. GTT 時の血清 insulin 反応は, Fig. 6 に示した. 
Fig. 4. Fasting serum insulin levels

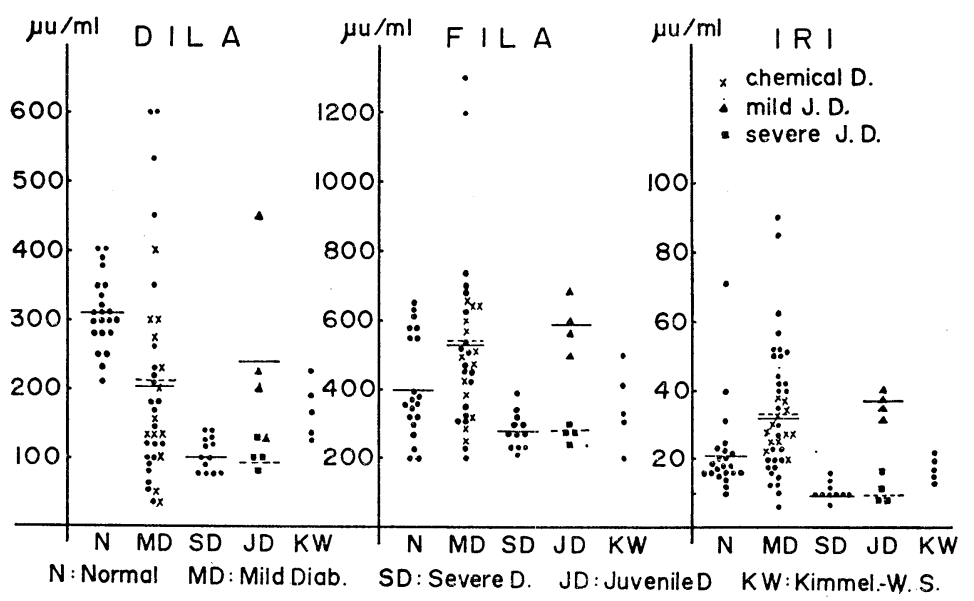

Fig. 5. Blood sugar during GTT in normal subjects

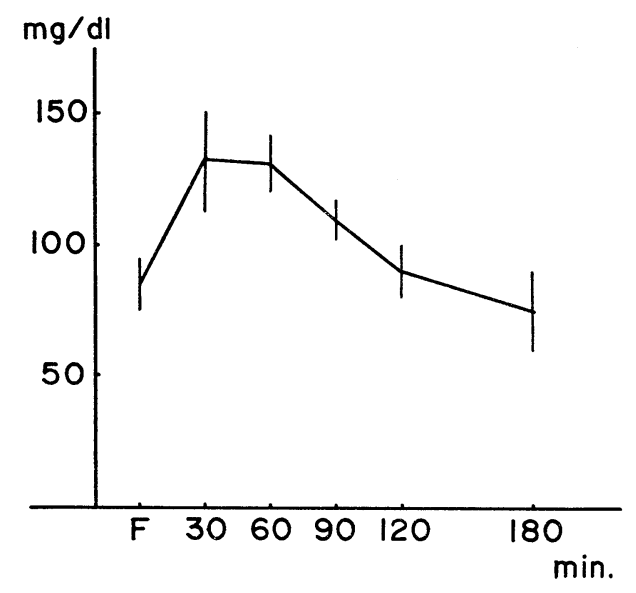

正常者に於ては，血糖の頂值は負荷後 30分にあり， ILA 及び IRI の頂值は60分にあり，各々の值は， DILA $673 \mu \mathrm{u} / \mathrm{ml}\left(\mathrm{SD}_{ \pm 114}\right)$, FILA $821 \mu \mathrm{u} / \mathrm{ml}\left(\mathrm{SD}_{ \pm}\right.$ 168) 及び IRI は $78 \mu \mathrm{u} / \mathrm{ml}(\mathrm{SD} \pm 13.2)$ であつた。即 ち，血糖の上昇が膵ラ氏島の $\beta$ 細胞に働いて insulin 分泌が促された事を示している。血糖と同様に ILA 及び IRIも120分では前值に復し，血糖と ILA 及び IRI の反応がよく平行した。負荷後60分 DILA 及び FILA は前值の約 2 倍に堌加しでおり, IRI は前値 の約 4 倍に増加している.

B) 糖尿病患者群

1) 空腹時值

i）軽症群

空腹時血糖值は, 86〜 $182 \mathrm{mg} / \mathrm{dl}$ で，平均空腹時血 糖值は, $131 \mathrm{mg} / \mathrm{dl}(\mathrm{SD} \pm 30)$ であつた. (Fig. 7) 空腹

Fig.6. Serum insulin response during GTT in normal subjects

$D$ I L A

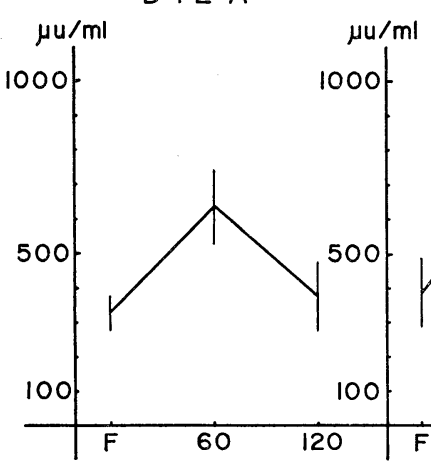

$F \perp L A$

| R I 
Fig. 7. Blood sugar during GTT in mild diabetics

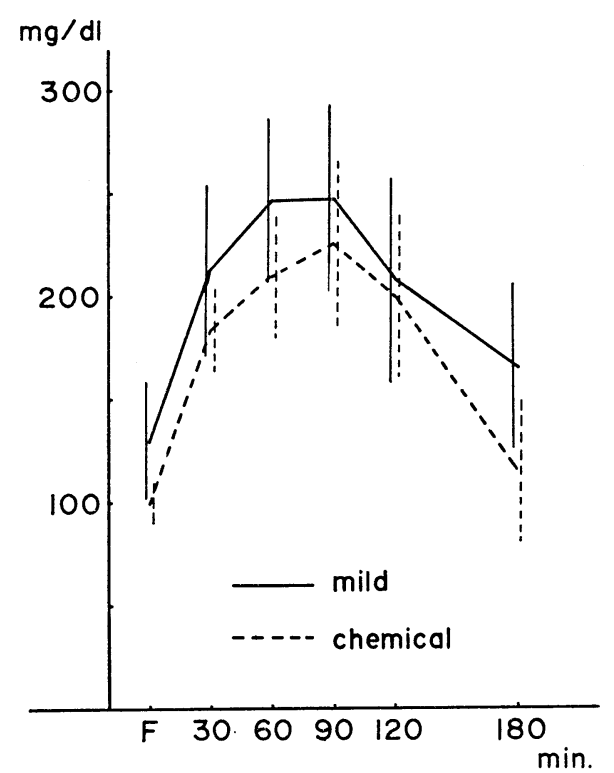

時血糖值太泟常範因にあるものでも，ブドー糖負荷後 の血糖の頂值は, $170 \mathrm{mg} / \mathrm{dl}$ 以上で, 全て糖尿病と診 断された。乙れらの患者は，臨床症状はなく， chemical diabetes で, 空腹時平均血糖值は $202 \mathrm{mg} / \mathrm{dl}$ $(\mathrm{SD} \pm 21)$ であつた。軽症群の DILA は, 例外的に 2 例は $400 \mu \mathrm{u} / \mathrm{ml}, 450 \mu \mathrm{u} / \mathrm{ml}$ と高かつたが, 平均空 腹時 DILA は， $203 \mu \mathrm{u} / \mathrm{ml}\left(\mathrm{SD}_{ \pm} 74\right)$ と, 正常值よ り低くかつた。空腹時 FILA は, 200〜 $1600 \mu \mathrm{u} / \mathrm{ml}$ で，平均空腹時 FILA は $531 \mu \mathrm{u} / \mathrm{ml}\left(\mathrm{SD}_{ \pm 92)}\right.$ で, DILA とは逆に正常值より高かつた。 FILA は， 2 例は $1600 \mu \mathrm{u} / \mathrm{ml}$ 及び $1200 \mu \mathrm{u} / \mathrm{ml}$ と黑常に高く, 亦, 3 例は $300 \mu \mathrm{u} / \mathrm{ml}$ 以下の $200,215,230 \mu \mathrm{u} / \mathrm{ml}$ と低 かつた。これらの 5 例を除くと $380 \mu \mathrm{u} / \mathrm{ml}$ から 740 $\mu \mathrm{u} / \mathrm{ml}$ の範囲にあつた. IRI は $6.4 \sim 90 \mu \mathrm{u} / \mathrm{ml}$ の範 囲にあり, $6.4 \mu \mathrm{u} / \mathrm{ml}$ と $10 \mu \mathrm{u} / \mathrm{ml}$ の 2 例の低いもの もあつたが, 平均空腹時 IRI は $32.8 \mu \mathrm{u} / \mathrm{ml}\left(\mathrm{SD}_{ \pm} 9.6\right)$ で, 正常值より高かつた。

chemical diabetes の DILA は, $130 \sim 400 \mu \mathrm{u} / \mathrm{ml}$ で, 平均空腹時 DILA は, $226 \mu \mathrm{u} / \mathrm{ml}(\mathrm{SD} \pm 87)$ で,

正常值より低かつた。しかし，1例では $400 \mu \mathrm{u} / \mathrm{ml}$ と高かつた. FILA は $380 \sim 665 \mu \mathrm{u} / \mathrm{ml}$ で, 平均空腹時 FILA は $540 \mu \mathrm{u} / \mathrm{ml}(\mathrm{SD} \pm 91)$ で正常值より高かつた. IRI は $23 \sim 38 \mu \mathrm{u} / \mathrm{ml}$ で, 平均空腹時 IRI は 32.7 $\mu \mathrm{u} / \mathrm{ml}\left(\mathrm{SD}_{ \pm} 5.5\right)$ で, 正常值より高かつた。 以上の如く, 正常対象群に比べ DILA は低く, FILA 及び IRI は高かつた. 亦, chemical diabetes との間には, 差異は認められなかつた。 これらの值は Fig. 4 に 示したが，×印は chemical diabetes の值を示している.

\section{ii）重症群}

空腹時血糖値は 228〜 319mg/dl で，平均空腹時血糖值は $269 \mathrm{mg} / \mathrm{dl}(\mathrm{SD} \pm 31)$ であつた. (Fig. 9) DILA は $80 \sim 135 \mu \mathrm{u} / \mathrm{ml}$ で軽症群より更に低く, 平均空腹時 DILA は $100 \mu \mathrm{u} / \mathrm{ml}\left(\mathrm{SD}_{ \pm} 22\right)$ で, 重症になる程空 腹時 DILA は低くなつた. FILA は 225 390 $\mu \mathrm{u} / \mathrm{ml}$ で, 軽症群では正常群より高かつたものが, 本群で は低值となり, 空腹時 FILA は $276 \mu \mathrm{u} / \mathrm{ml}(\mathrm{SD} \pm 45)$ であつた. IRI FILA と同じ傾向で, 空腹時 IRI は 7.4 $14 \mu \mathrm{u} / \mathrm{ml}$ で, 平均空腹時 IRI は $9.3 \mu \mathrm{u} / \mathrm{ml}(\mathrm{SD} \pm 1.9)$ であつた. 以上の如く, 糖尿病では, DILA

Fig. 8. Serum insulin response during GTT in mild diabetics

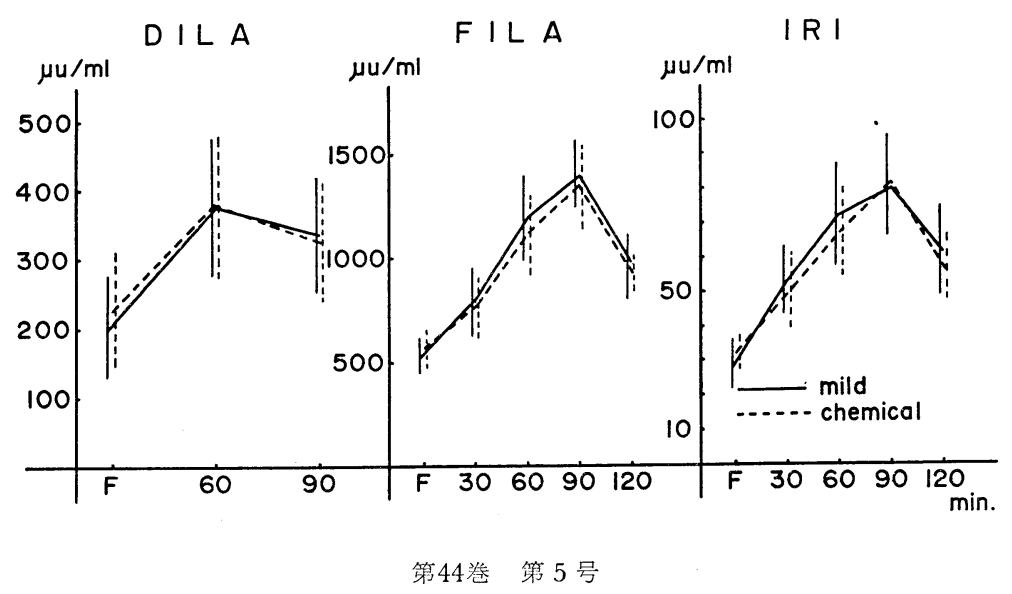


Fig. 9. Blood sugar during GTT in severe diabetics

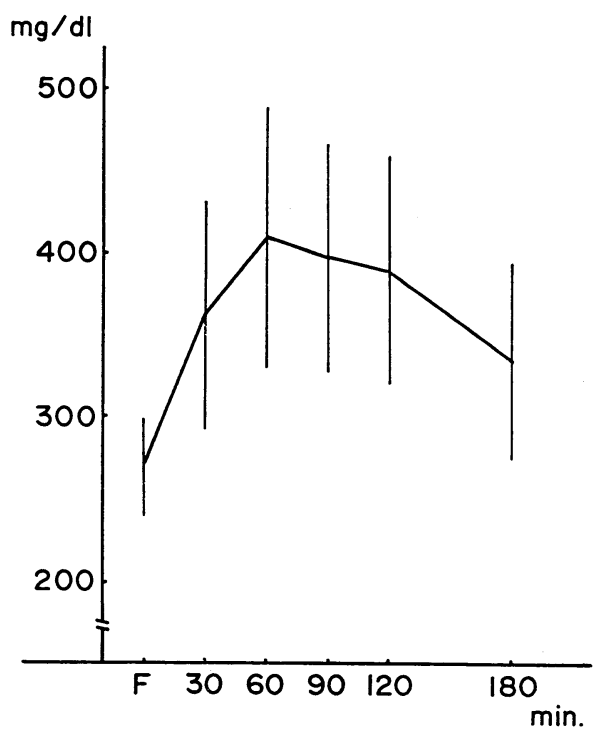

は常に低く，重症になると更に低くなり，FILA 及び IRI は軽症群ではやや高く, 重症になると何れも低く なつた。

iii）若年性糖尿病患者群

本群は, insulin の絶対的不足によると考えられて いる，そこで若年性糖尿病のみについて 検討した。

Fig. 4 に示した如く，本群が絶対的な insulin 不足 による事を証明する特徴的所見は得られなかつた。軽 症例の空腹時血糖值は $119 \sim 170 \mathrm{mg} / \mathrm{dl}$ で, 平均空腹 時血糖值は $134 \mathrm{mg} / \mathrm{dl}\left(\mathrm{SD}_{ \pm} 21\right)$ (Fig. 11 実線) DILA は 1 例 $450 \mu \mathrm{u} / \mathrm{ml}$ と高值であつたが，他の 3 例では $130 \sim 200 \mu \mathrm{u} / \mathrm{ml}$ で, 平均空腹時 DILA は $240 \mu \mathrm{u} / \mathrm{ml}$ $(\mathrm{SD} \pm 123), \mathrm{FILA}$ は $500 \sim 690 \mu \mathrm{u} / \mathrm{ml}$ で, 平均空腹時 FILA は $590 \mu \mathrm{u} / \mathrm{ml}(\mathrm{SD} \pm 68)$, IRI は 33〜 40 $\mu \mathrm{u} / \mathrm{ml}$ で，平均空腹時 IRI は $37 \mu \mathrm{u} / \mathrm{ml} \quad(\mathrm{SD} \pm 2.6)$ であつ た. (Fig. $4 \times$ 印) 即ち, 軽症群と全く同じ傾向を示 した. 重症例では, 空腹時血糖值は 228〜 $270 \mathrm{mg} / \mathrm{d} 1$ で, 平均空腹時血糖值は $248 \mathrm{mg} / \mathrm{dl}(\mathrm{SD} \pm 16)$ であつ た. (Fig. 11 点線) DILA は 85〜 $100 \mu \mathrm{u} / \mathrm{ml}$ で平均

Fig. 10. Serum insulin response during GTT in severe diabetics

$D$ I L A

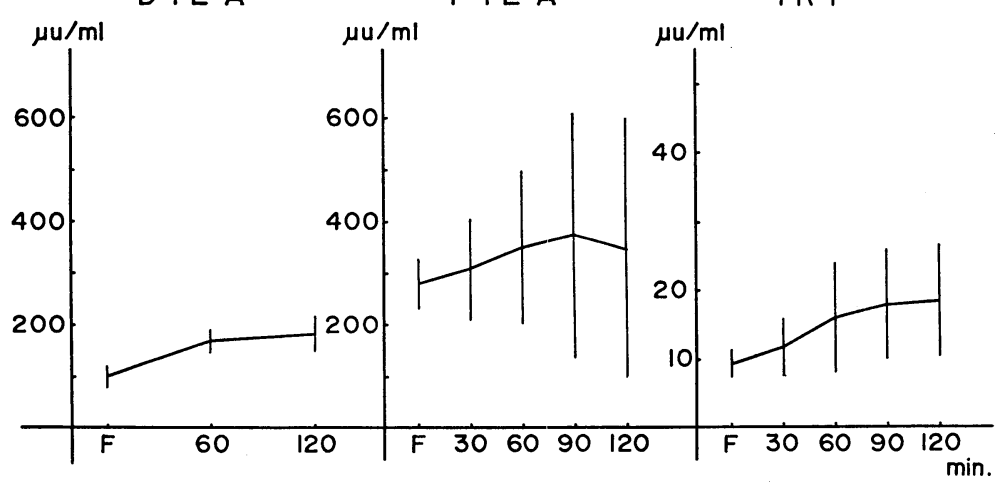

空腹時 DILA は $93 \mu \mathrm{u} / \mathrm{ml}(\mathrm{SD} \pm 7)$ であり, FILA は $240 \sim 302 \mu \mathrm{u} / \mathrm{ml}$ で, 平均空腹時 FILA は $275 \mu \mathrm{u} /$ $\mathrm{ml}\left(\mathrm{SD}_{ \pm 22}\right.$ ). IRI は 7.6〜 $11.6 \mu \mathrm{u} / \mathrm{ml}$ で, 平均空腹時 IRI は $9.5 \mu \mathrm{u} / \mathrm{ml}\left(\mathrm{SD}_{ \pm} 1.7\right)$ であつた。 (Fig. 4 ・印) 重症例は，DILA，FILA 及び IRI 共に正常值より低く，当然の事ではあるが，重症群と全く同じ傾向で あつた，従つて，若年性糖営病でも血中 insulin は重症度による差異が認められたに過ぎなかつた。

iv) Kimmelstiel-Wilson 症候群

空腹時血糖值は，120～180mg/dl あつた (Fig. 13). DILA は 150〜250 $\mu \mathrm{u} / \mathrm{ml}$ で，低值であつた。. FILA は $185 \sim 500 \mu \mathrm{u} / \mathrm{ml}$ で, やや低いものが 2 例, やや高いものが 1 例, 2 例は正常範囲にあつた. IRI は 13〜 $24 \mu \mathrm{u} / \mathrm{ml}$ で, 低いものが 2 例で, 正常範囲のものが 3 例あつた。 以上の如く, 空膜時の ILA 及び IRI に ついては, 少数例の為か, 一定の傾向が認められなかつた。しかし, 空腹時血糖值 $200 \mathrm{mg} / \mathrm{dl}$ でも, FILA の低い症例か認められた，それには，治療の影響も全く否定は出来ないと考える (Fig. 14). 
Fig. 11. Blood sugar during GTT in juvenile diabetics

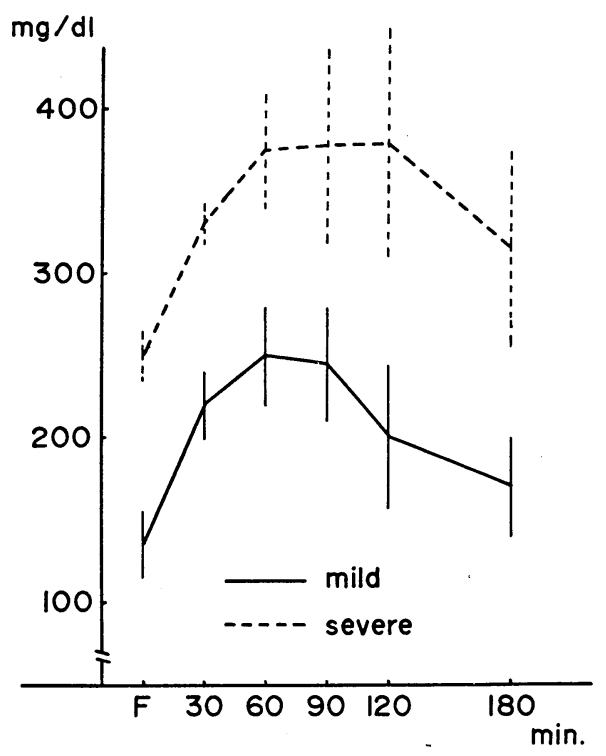

2） GTT と血清 insulin の変動

i) 軽症群

GTT の平均血糖曲線は Fig. 7 の実線で示した如 く, 負荷後60分又は90分で頂值に達し，120分でも血 糖 $166 \mathrm{mg} / \mathrm{dl}$ で前值に復さず，耐糖能の低下を珰め た. DILA は, 前述の如く, 前値は $203 \mu \mathrm{u} / \mathrm{ml}$ で, 既に正常值より低く，負荷後，DILA は上昇するが 頂值は $373 \mu \mathrm{u} / \mathrm{ml}\left(\mathrm{SD}_{ \pm} 96\right)$ で, 正常值より低かつた。 120分では $335 \mu \mathrm{u} / \mathrm{ml} \quad\left(\mathrm{SD}_{ \pm} 76\right)$ と下降するが，前值 に復していない. FILA の前值は $527 \mu \mathrm{u} / \mathrm{ml}$ と高く, 負荷後, 著しく上昇し90分で頂值 $1402 \mu \mathrm{u} / \mathrm{ml} \quad\left(\mathrm{SD}_{ \pm}\right.$ 166）に達し，過剰反応を呈し，正常者に比べて頂值 の遅延が諗められ，120分でも $960 \mu \mathrm{u} / \mathrm{ml}(\mathrm{SD} \pm 117)$ で，前値に復さなかつた． IRI の前值は $28.8 \mu \mathrm{u} / \mathrm{ml}$ で高いが，負荷後の IRI の上昇は，正常者と同程度 であつた，しかし，頂值の遅延が認められた（Fig. 8 実線).

chemical diabetes の GTT の平均血糖曲線は Fig. 7 の点線で示した如く, 前值 $102 \mathrm{mg} / \mathrm{dl}$ 90分を頂 值 $227 \mathrm{mg} / \mathrm{dl}\left(\mathrm{SD}_{ \pm} 41\right)$ とし, 120分值 $199 \mathrm{mg} / \mathrm{dl}\left(\mathrm{SD}_{ \pm} 48\right)$ と軽症群より常に低くかつた. しかし, DILA, FILA 及び IRI は, 軽症群と全く一致し, DILA の頂值の低下 FILA の過剩及び遅延反応, IRI の遅延 反応が認められた。 (Fig. 8 点線)

従つて, chemical diabetes は, 軽症群の中では血糖值は低いが, ILA 及び IRI は, 軽症群のそれと差 異は認められなかつた。

ii) 重症群

GTT の平均血糖曲線は，Fig. 9 そ示した。前值 $269 \mathrm{mg} / \mathrm{dl}$ で，頂值は，60分で $410 \mathrm{mg} / \mathrm{dl}(\mathrm{SD} \pm 81)$, 120分で で 388mg/dl (SD士73) あつた. DILA は，60分で $166 \mu \mathrm{u} / \mathrm{ml}\left(\mathrm{SD}_{ \pm 22}\right)$ で，僅かに上昇し， 120 分でも $181 \mu \mathrm{u} / \mathrm{ml}(\mathrm{SD} \pm 40)$ と更に僅かに上昇し，頂值の低下及び遅延が認められた．FILA は，90分を頂 . 值 $371 \mu \mathrm{u} / \mathrm{ml}\left(\mathrm{SD}_{ \pm} 242\right)$ として僅かに上昇し，120分で $344 \mu \mathrm{u} / \mathrm{ml}\left(\mathrm{SD}_{ \pm} 251\right)$ と下降しているが，前值には復

Fig. 12. Serum insulin response during GTT in juvenile diabetics

D I L A

F I L A

I R I

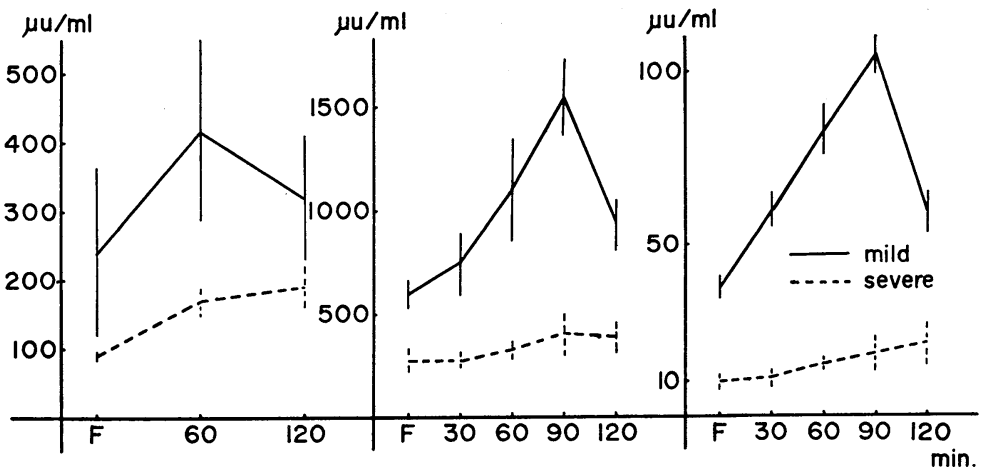

第 44 巻 第 5 号 
Fig. 13. Blood sugar during GTT in Kimmelstiel-Wilson's syndrome

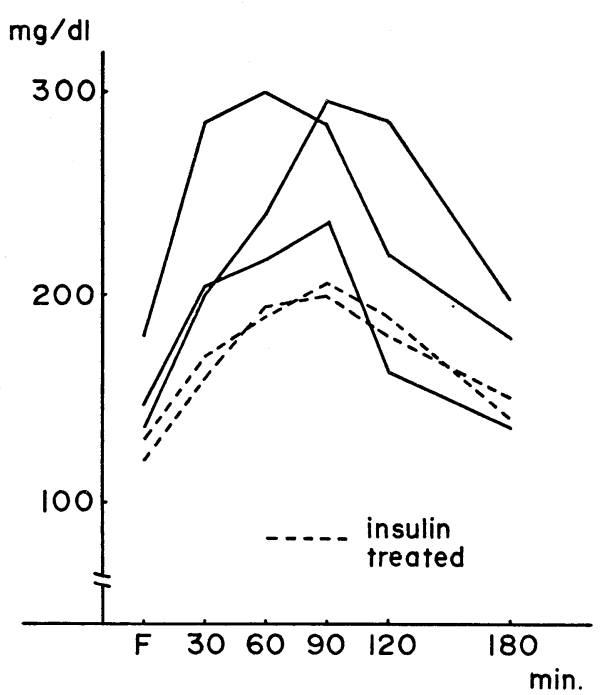

さなむつた. 即ち, FILA でも頂值の低下及び遅延が 認められた。 本群では, GTT で FILA が30分及び 60分で下降し，90分及び120分で僅かに上昇するもの が誌められ，insulsn 分泌の著しい遅延を示した。 IRI は, 前值 $9.3 \mu \mathrm{u} / \mathrm{ml}$ で, 30分值, $11.6 \mu \mathrm{u} / \mathrm{ml}$ (SD $\pm 4.5), 60$ 分值, $16.6 \mu \mathrm{u} / \mathrm{ml}\left(\mathrm{SD}_{ \pm} 8.0\right), 90$ 分值 $17.7 \mu \mathrm{u}$ $/ \mathrm{ml}\left(\mathrm{SD}_{ \pm} 8.0\right)$ で, 120 分值 $18.4 \mu \mathrm{u} / \mathrm{ml}\left(\mathrm{SD}_{ \pm} 8.5\right)$ を 頂值として平担に僅かに上昇し続け, 頂值の遅延と低 下が認められた，以上の如く，本群では，ILA 及び IRI 共任前值も低く, GTT 亿対する insulin 分泌 も最も少なく, 膵島の機能障害の著しい事を現わして いる。

\section{iii）若年性糖尿病患者群}

GTT の平均血糖曲線を，Fig. 11 亿示した。㿤線 は軽症例を, 点線は重症例を表をしている。前值は軽 症例 $134 \mathrm{mg} / \mathrm{dl}(\mathrm{SD} \pm 21)$ 重症例 $248 \mathrm{mg} / \mathrm{dl}(\mathrm{SD} \pm 16)$ で, 軽症例は60分を頂值 $249 \mathrm{mg} / \mathrm{dl}(\mathrm{SD} \pm 31)$ とし, 重症群は60分からゆるやかに120分迄上昇し続け，120

Fig. 14. Serum insulin response during GTT in Kimmelstiel-Wilson's syndrome

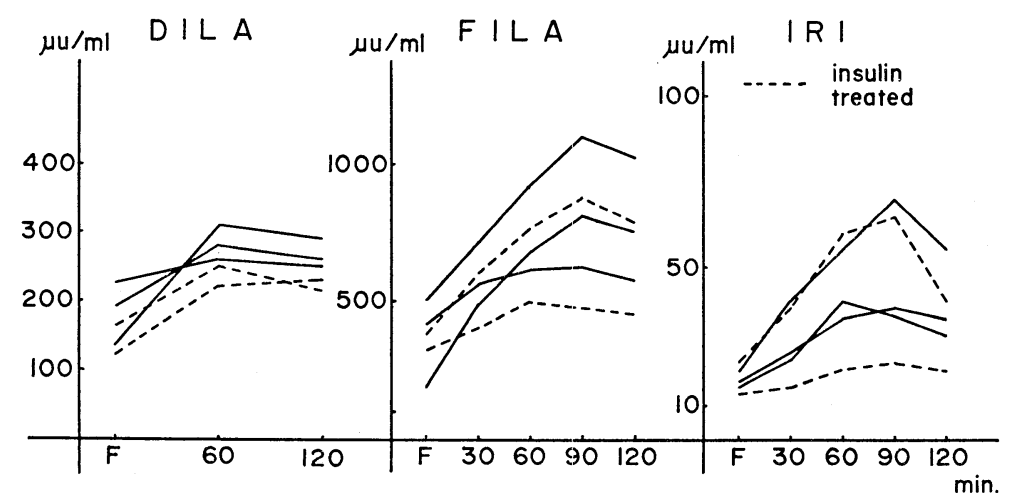

分を頂值 $378 \mathrm{mg} / \mathrm{dl}\left(\mathrm{SD}_{ \pm} 64\right)$ として，180分では軽症例 $169 \mathrm{mg} / \mathrm{dl}(\mathrm{SD} \pm 31)$ 重症群 $316 \mathrm{mg} / \mathrm{dl}\left(\mathrm{SD}_{ \pm} 64\right)$ に下降した。 即ち, 軽症例では, DILA は, 前值 $240 \mu \mathrm{u} / \mathrm{ml}\left(\mathrm{SD}_{ \pm 123}\right)$ で, 正常值よりやや低く, 60分で 頂值 $415 \mu \mathrm{u} / \mathrm{ml}(\mathrm{SD} \pm 141)$ となり，120分で $320 \mu \mathrm{u} / \mathrm{ml}\left(\mathrm{SD}_{ \pm} 90\right)$ と下降したが，前值には復さなかつた. FILA は，前值が $590 \mu \mathrm{u} / \mathrm{ml}(\mathrm{SD} \pm 68)$ と正常值より高く, 90分で頂值 $1550 \mu \mathrm{u} / \mathrm{ml}\left(\mathrm{SD}_{ \pm} 166\right)$ と著しく高 く, 更に遅延し，120分でも $1025 \mu \mathrm{u} / \mathrm{ml}(\mathrm{SD} \pm 125)$ と下降した. IRI は, 前值 $37.0 \mu \mathrm{u} / \mathrm{ml}\left(\mathrm{SD}_{ \pm} 2.6\right)$ で, 正常值より高く, 90分で頂值 $95 \mu \mathrm{u} / \mathrm{ml}(\mathrm{SD} \pm 9.5)$ と高く, 頂值は遅延し, 120 分では, $59 \mu \mathrm{u} / \mathrm{ml}\left(\mathrm{SD}_{ \pm} 12.5\right)$ と下降した．各々の頂值は，DILA では正常值より低く，FILA 及び IRI では高く遅延反応を示した，亦， 軽症群より全体的にやや高かつた。

重症群では，DILA は前值 $93 \mu \mathrm{u} / \mathrm{ml}\left(\mathrm{SD}_{ \pm} 7\right)$ で低く，120分で頂值 $169 \mu \mathrm{u} / \mathrm{ml}(\mathrm{SD} \pm 23)$ となり，頂值 の低下及び遅延が認められた. FILA は前值 $275 \mu \mathrm{u} / \mathrm{ml}(\mathrm{SD} \pm 22)$ と低く, 90 分で頂值 $399 \mu \mathrm{u} / \mathrm{ml}\left(\mathrm{SD}_{ \pm} 101\right)$ で低く，120分で $388 \mu \mathrm{u} / \mathrm{ml}\left(\mathrm{SD}_{ \pm} 82\right)$ と下降した. IRI は前值 $9.5 \mu \mathrm{u} / \mathrm{ml}$ で低く，120分で頂值 $21.0 \mu \mathrm{u} / \mathrm{ml}$ 
( $\left.\mathrm{SD}_{ \pm} 6.4\right)$ と低くかつた。 従つて DILA FILA 及び IRI で過少遟延反応を呈した.

\section{iv) Kimmelstiel-Wilson 症候群}

GTT の血糖曲線を Fig. 13 亿示した。点線は, 治療中の症例であり, 実線は治療不充分な症例である. 治療不充分の 3 症例では, 空腹時血糖は, $200 \mathrm{mg} / \mathrm{dl}$ 以下であるが, 糖負荷後, 血糖は著しく上昇した。 DILA は, 前值は低く, 糖負荷後も頂值の低下を示した. FILA は, 前值の高い 1 例は負荷後, 過剩反応 を旺し， 2 例は頂值の遅延が認められ，残り 2 例は頂值の低下が認められた．

IRI は, 前值が正常範囲にある 2 例で頂值の遅延を, 他の 3 例で頂值の低下及び遅延が喼められた。 insulin 治療を受けた症例では全て低值であつた（Fig. 14)，糖負荷後の血清 insulin の反応に一定の傾向を認めな かつた。

\section{総括並びに考按}

生物学的測定法で測定された血清 ILA は，insulin 亿関係する事は明らかであるが，他の因子が，生物 学的測定法による血清 insulin の定量を阻止する多くの証明がある。殆んどの証明は, 横隔膜法を用いた実 験によるものではあるけれども，乙れらの因子は，副睪丸脂肪組織法でも阻此される様に思われる。しかし， 副辠丸脂肪組織法による血清 insulin 定量を阻止する程の因子が血中に存在するかどうか不明である，副睪 丸脂肪組織法では, insulin と同様の作用を, growth hormone, prolactin 及び corticotiophinが示すが, 横隔膜法では, これらの hormone が, glucose uptake を增強しない事 ${ }^{20)} は$, 興味深い. 生物学的測定法 で, insulin の定量を阻止する因子が，免疫学的測定法にも阻止的に働くとは考光られないが，免疫学的測 定法の insulin 特異性についても尚, 不明の点が多い.

本研究に用いた 3 つの測定法の内では, 免疫学的測定法が最も信恣性があると考えられている. 副童丸脂 肪組織組織法の指標に $\mathrm{CO}_{2}$ 産生を用いると, growth hormone, adrenalin, corticotrophin 等の作用は著し く減弱し，本法の insulin 特異性は満足すべきものである ${ }^{21)}$ との考えもあるが，少くとも glucose uptake を指標とするよりは, insulin 特異性は高いと思われる，以上の如く，現在用いられている血中 insulin 測 定法は，必ずしも満足すべきものではないが，てれらの成績を総合することにより，糖尿病の insulin の分 泌異常を幾らかでも説明しうるものと考光られる。

正常者のILA 及びIRI は, 多くの研究者により, 多くの異なつた方法で測定されてきた，空腹時 DILA は，各報告者により可成りの相違がある，Vallance-Owen ら ${ }^{22)}$ によると非稀勫血清で, 平均 $64 \mu \mathrm{u}(40 \sim 60$ $\mu \mathrm{u} / \mathrm{ml})$ であり，Seltzer 及び Smith ${ }^{23)}$ ほぼ同じ值を得ている。しかし，Willebrands ${ }^{24)} ら は ， 5$ 倍稀釈血清 で測定し， $100 〜 3000 \mu \mathrm{u} / \mathrm{ml}$ であつたと報告しており, 非稀採血清に比べ， 5 20倍の稀橎血清を用いる事 により, insulin 効果が增大することを見出し, 現在では, 専ら稀哷血清が用いられている。乙の様に測定 に使用する血清の稀釉が，大きな意義を持つている．吉田 ${ }^{8)}$, 奥村 ${ }^{19)}$ は，4倍稀釈血清を用いて，正常者平 均空腹時 DILA は $330 \mu \mathrm{n} / \mathrm{ml}(260 \sim 400 \mu \mathrm{u} / \mathrm{ml})$ であり, 辻ら $\left.{ }^{25}\right)$ も $100 \sim 500 \mu \mathrm{u} / \mathrm{ml}$ であつたと報告してお り，著者の成績と一致する。Vallance-Owen ${ }^{22)}$ Wright ${ }^{26)}$ は， 正常者にブド一糖を負荷すると，前值約 $60 \mu \mathrm{u} / \mathrm{ml}$ であつたものが, 負荷後 $100 \sim 800 \mu \mathrm{u} / \mathrm{ml}$ 亿増加したと報告しており, 著者の成績と一致し, 血糖 曲線と平行して変動した．FILA 亿就いても非稀哷血清より稀釈血清で高い值が報告されている． Lyngsoe

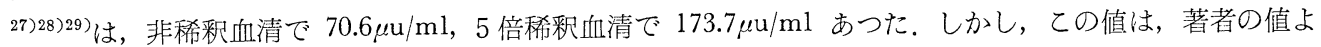
り低く, 著者の值は Martin $ら^{30)}$ 及び Daweke $~^{31)}$ と一致する。ブドー糖負荷後は, DILA と同様に上昇 し, Steinke ら ${ }^{32)}$ によると $3 \sim 6$ 倍に増加し, 著者の成績では, 2 倍に増加した. 空腹時 IRI は Berson ら 10) によると平均 $21 \mu \mathrm{u} / \mathrm{ml}(0 \sim 66 \mu \mathrm{u} / \mathrm{ml})$ で, Herbert $~^{16)}$ も同じ値で西り, 著者の成績と一致している. Charcoal 法は, free 及び bound insulin の分離䎲抗体を用いず操作が簡単で短時間に出来るので本研究 に採用した。ブド一糖負荷後 IRI も増加し, 諸家の報告によると約 $3 \sim 6$ 倍に増加し, 著者の成績も 4 倍 に增加した。亦, DILA. FILA, IRI はよく平行した.

従つて, 3 つの血中 insulin 測定法で各々多くの研究者の成績と一致し, 各々關違いなく血中insulin の 
動きをとらえているものと考える。

正常者の空腹時值について観察すると, ILA と IRI の值には著しい差異があり, 一般に認められた事実

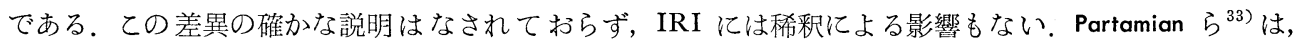
生物学的には活性であるが, 免疫学的には非活性の血清蛋白又は血清中の insulin の存在, 他の動物では insulin 作用を促進する様な hetero-specific factor の存在, 細胞表面で insulin 様作用を促進する intravasculary restricted protein の存在及び insulin の一部が AIS と反応しないような他の因子と給合して

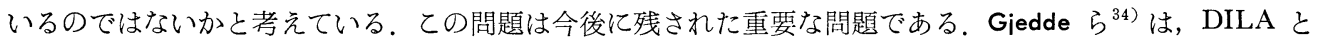
FILA の值は同じであつたと報告しているが，著者の成績では，FILA は DILA ょりやや高かつた。 ての 事は, 横陑膜法に対する inhibitor, 副辠丸脂肪組織法に対する activator も関与するかも知れていかが, Antoniades ら ${ }^{11}$ の唱える “free” 及び “bound” insulin の概念より当然の事であろう.

糖尿病患者の内, 軽症群では, 空腹時 DILA は低下し, FILA 及び IRI は増加していた. 亦, chemical diabetes でも同じ傾向であつた。奥村 ${ }^{19)} も$ DILA は糖尿病患者で低いてとを認めている．Steinke ら ${ }^{36)}$ は， prediabetes 及び overt diabetes の空腹時 FILA が正常者より高く, 之は高血糖に対する二次的反応であ ると共に, 筋肉組織に対する insulin antagonist の増加とよると述べている. 空腹時 IRI は, 正常者に比 べて高いと，Yalow ら ${ }^{37}$ は報告している，GTT に対する insulin 反応を見ると，DILA は全例で正常者， に比べて頂值が低く, FILA は過剩遅延反応が認められ，IRI は頂值は正常範囲であるが，遅延反応を示 した. Vallance-Owen ら ${ }^{38)}$ も横隔膜法を用いて若年性糖尿病で GTT に対する内因性 insulin の動員は不 充分であつたと述べ, Seltzer 及び Smith ${ }^{23)}$ も insulin 分泌は不充分であり，之は，“insulogenic reserve” の減弱によると考えている. Alp ら ${ }^{54}$ そよると FILA は, $\mathrm{CO}_{2}$ 産生を指標とすると過剩反応であつたが, lipid への転換を指標とすると有意の上昇を認めなかつた，Power ら ${ }^{39)}$ は，著者と同様，過剩反応を認めて いる，FILA は，指標を異にすれば異なつた成績が出る可能性があるてとを示唆している．

Buchanan ら ${ }^{40)}$ による，GTT に対する IRI の遅延反応は，糖尿病に特徵的であるが，それは，ブドー 糖の insulin に対する刺激の闇值の上昇を示しているのか insulin の合成又は分泌潩常があるのか不明 であると述べている。一方 Berson ら ${ }^{41} は$, 過剩遅延反応が特徽的であると報告している。従つて, 軽症糖尿 病及び chemical diabetes では，立分ではないが相当量の insulin が糖刺激によつて分泌されるにも抱らず, DILA に対する antagonist の増加, FILA に対する activator $\left.{ }^{35}\right)$ の作用によつて非常に複雑な insulin 像を

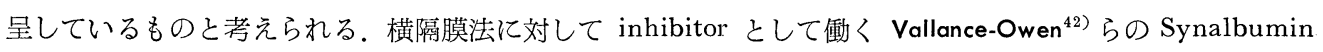
又は TCA-ethanol extract は, 糖尿病で阻害作用が強いが, 副睪丸脂肪組織法では, activator として働く ${ }^{43)}$ ことより, 糖尿病では DILA が低く, FILA は高いのであろう。重症群では, 空腹時 DILA は勿論, FILA 及び IRI も低值を示した．Ketoacidosis では DILA は検出出来ず3)，FILA，IRIも重症になると低下す る事が認められている ${ }^{44), 45)}$. 亦, GTT でも DILA，FILA 及び IRI の反応は減弱し，過少遅延反応とな り，乙れ迄の報告を支持している3 ${ }^{2346) 40}$ ） 従つて，重症糖尿病では， antagonist の増加に対する代償性 insulin 分泌に耐えられず, 膵 $\beta$ 細胞の疲幣を来し, insulin 分泌機能の著しい低下を示唆している. FILA では, 糖負荷後, 30分, 90分で減少し, その後, 增加傾向を示すものがあり, 著しい insulin の分泌遅延と 考えられるが, この様な例で, DILA 及び IRI は糖負荷後, 増加は少ないが, 少なくとも, 減少傾向は見 られず，FILAのみに見られた事を充分説明出来なかつた，今後の検討を要する点である，しかし，阿部 ら ${ }^{47)}$ は, 糖尿病患者に GTT を行なつて, FILA のみを測定し, 糖負荷後 FILA の増大を認めなかつた と報告し, この FILA 反応が糖尿病の特徴であると述べている.

若年性糖尿病患者は, 空腹時及び糖負荷後共に DILA は低值であつた事は, 従来の報告に一致する. 空 腹時 FILA に関しては高いとの報告 ${ }^{32499}$ が多く, 昏睡に近い未治療の若年性糖尿病に於いても高かつたと Beigelman ら ${ }^{50}$ は報告している. しかし，Fig.4 亿示した如く, 軽症例では高かつたが, 重症例では低かつ た。空腹時IRI は低く, insulin deficiency であると Berson ${ }^{45)}$ 及び Buchanan ${ }^{40)}$ は述へているが, Johansen 及び Lundback ${ }^{51)}$ にると若年性軽症糖尿病の IRI の動態は, 成人型糖尿病のそれによく似ているといつて 
いる。糖負荷に対しても, 軽症例は軽症群の, 重症例は重症群の血清 insulin 動態を示し, Johansen 及び Lundback の成績を支持した. Berson 及び Buchanan との成績の違いは対象を異にしている為かもしれない. 亦, Elliot 弓 ${ }^{52)}$ は，若年性糖尿病の血清 insulinの insulinase による分解率が，正常者と異るととにより， 異常 insulin の分泌を想定し, 糖尿病と遺伝との関連性があるのではないかと想定している.

Kimmelstiel-Wilson 症候群は, 長期に亘る糖尿病䍜患の末にたどりついた糖尿病性血管合併症の完成像 であると考えて，少数例ではあるが検討した。しかし，全く未治療のまま，本症候群を診るととは稀であ り, 従つて, 血中 insulin そついての報告も殆んぞ見られない. 山田ら ${ }^{53)}$ は in vivo の insulin 測定法を 用いての報告で, 血管合併症を有する糖尿病は, 合併症のない糖尿病に比し, 血中 ILA の低下を認め, 合 併症の頻度が増す程低下する傾向を認めている，著者の成績でも，ILA 及び IRI の低下しているものも認 められるが，一定の傾向が得られなかつた。

\section{結語}

ラット剔出横隔膜法, ラット剔出副睪丸脂肪組織法及び免疫学的測定法を同一材料に用いて, 糖尿病患者 の血清 ILA 及び IRI を測定した.

軽症群の空腹時 FILA 及び IRI は正常者に比べて高く, 多量の insulin が分衍されていると考えられ るが，DILA は低く，筋肉組織に対しての insulin 作用は低下している，又，その為にてそ代償性に多量 の insulin が分泌されているのであろう。糖刺激に対して, DILA は過少反応, FILA は過剩遅延反応, IRI は遅延反応であつた. chemical diabetes 軽症群と差異を認めなかつた。 従つて, 軽症群では DILA を下げる DILA-inhibitor が重要な因子である. 重症群では, 空腹時 DILA, FILA 及び IRI 三者共に低 く, 糖刺激に対して三者共に過少反応であつた。即ち, 重症群では insulin 分泌の低下が認められる.

若年性糖尿病及び Kimmelstiel-Wilson 症候群では, 特徽的所見が得られなかつた.

3 つの血清 insulin 測定法を用いるととにより，DILA-inhibitor が糖尿病発症に重要な因子として働く ととを認めた.

今後新しい insulin 測定法が見出されない限り, 糖尿病の病態の研究には, 本研究に用いた 3 つの血中 insulin 測定法を用いる必要がある.

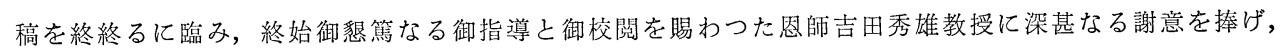
種々御教示頂いた奥村賢太郎講師及び故富川哲夫博士に深謝の意を表します。尚, 本研究に御協力頂いた阿 部信行, 阿部敦両学士に感謝致します。

\section{文献}

1) HEMmingSEN, A.E. : Acta Med. Scandinav., $90: 105$, (1938). 2) ANDERSON, E. : Proc. Soc. Exp. Biol. and Med., $94: 321$, (1957). $\quad 3$ 3) BORNSTEIN, J. : Australian J. Exp. Biol. and Med. Sc., $28: 87,(1950) . \quad 4)$ GEMMILL, C.L. : Johns Hopk. Hosp. Bull., $66: 232$, (1940). 5) VALLANCE-OWEN, J. : Lancet, $1: 983$, (1954). $\quad$ 6) GUNNINGHAM, N.F. : J. Endocrin., 25 : 35, (1962). 7) RANDLE, P.J. : Brit. Med. J. : $1: 1237$, (1954). 8) 吉田秀雄 : 糖尿病, 2 : 11, (1959). 9) RENOLD, A.E., A. MARBLE and D.W. FAWCETT : Endocrinology, $46: 55$, (1950). 10) BERSON, S.A. and YALOW, R.S. : J. Glin. Invest., $39: 1157$, (1960). 11) ANTONIADES, H.N. : Endocrinology, $68: 7$, (1961). DEMPSTER, W.J. : Diabetes, $12: 339$, (1963).

12) SAMAAN, N., FRASER,R. and DAGENAIS, Y.M. : J. Clin. Invest., $39: 1487$, (1960). 13) RENOLD, A.E., MARTIN, D.B. and 14) DITSGHUNEIT, H., CHANG-SU AHN, PFEIFFER, M. and PFEIFFER, E.F. : Klin. Wschr., 37 : 1234，(1959). 15) 富川哲夫：日 本内分泌学会雑誌, $42: 814$, (1966). 16) HERBERT, V., K. LAU, C.W. GOTTLIEF and S.J. BLEICHER : J. Clin. End., $25: 1375$, (1965). 17) 吉田秀雄, 他 : 日本内分泌学会雑誌, $44: 181$, 
(1968). 18) HAGEDORN, H.C., HALSTRÖM, F. and JENSEN NORMAN : Hospitalstidende, 78 ：1193 (1935). 19）奥村賢太郎：日本内分泌学会雑誌，35：5164，(1960)。20) RANDLE, P.J. and TAYLOR, K.W. : Brit. Med. Bull., $16: 209$, (1960). 21) SHEPS, M.C., NICKERSON, R.J., DAGENAIS, Y.M., STEINKE, J., MARTIN. D.B. and RENOLD, A.E. : J. Clin. Invest., 39 : 1449, (1969). 22) VALLANCE-OWEN, J. and HURLOGK, B. : Lancet, $1: 68$, (1954a). 23) SELTZER, H.S. and SMITH, W.L. : Diabetes, $8: 417$, (1959). 24) WILLEBRANDS, A.F. and GROEN, J. : Diabetes, $5: 328$, (1956). 25）辻昇三, 他：日本内分泌学会雑誌, 34:31, (1958). 26) WRIGHT, P.H. : Lancet, 6 : 261, (1967). 27) LYNGSOE, J. : Acta Med. Scandinav., 171 : 356, (1962). 28) LYNGSOE, J. : Acta Med. Scandinav., 172:41, (1962). 29) LYNGSOE, J. : Acta Med. Scandinav., $172: 601$, (1962). 30) MARTIN, D.B. and DAGENAIS, Y.M. : Lancet, $2: 76$, (1958). 31) DAWEKE, H. and BACHI, I. : Metabolism, $12: 319$, (1963). 33) STEINKE, J., TAYLOR, K.W. and RENOLD, A.E. : Lancet, $1: 30$, (1961). 33) PAR'TAMIAN, J., E. RASIO and G.F. GAHILL : Metabolism, $15: 60$, (1966). 34) GJEDDE, F. : Acta Endocrinologica, $57: 330$, (1968). 35) 吉田秀雄：日本内分泌学会䧴誌, $42: 611$, (1966). 36) STEINKE, J., J.S. SOELDNER, R.A. GAMERINI-DAVALOS and A.E. RENOLD : Diabetes, 15 : 502, (1963). 37) YALOW, R.S. and BERSON, S.A. : Diabetes, $9: 254,(1960) . \quad 38)$ VALLANCE-OWEN, J., B. HURLOCK and N.W. PLEASE : Lancet, $2: 583$, (1955). 39) POWER, L., BERNARDO REYES-LEAL and J.W. CONN : Metabolism, $13: 1297,(1964)$. 40) BUCHANAN, K.D. and McKIDDIE, M.T. : Diabetes, $16: 466$, (1967). 41) BERSON, S.A. and YALOW, R.S. : Diabetes, $14: 549,(1965) . \quad 42)$ VALLANGE-OWEN, J., DENNES, E. and CAMPBELL, P.N. : Lancet, 2 : 336, (1958). 43) 吉田秀雄 : 日本内分泌学会雑誌, $43: 574$, (1967). 44) BEIGELMAN, P.M. and TRANQUADA, E.T. : Diabetes, $9: 254$, (1960). 45) BERSON, S.A. and YALOW, R.S. : Ciba Found. Colloq. on Endocr., $15: 182$, (1962), Churchill, London. 46) DAVID, N. PHEAR : Lancet, $1: 955,(1962) .47)$ 阿部正和, 他 : 糖沓病, $8: 178,(1965)$ 4 48) BAIRD, C.W. and BORNSTEIN, J. : Lancet, $1: 111$, (1957). 49) DAWEKE, H. : Acta Endocrinologica, $46: 124$, (1964). 50) BEIGELMAN, P.M. and TR.ANQUADA, E.T. : Diabetes, $11: 179$, (1962). 51) JOHANSEN, K. and LUNDBAGK, K. : Lancet, $1: 1257$, (1967). 52) ELLIOT, R.B., D.O 'BRIEN and C.C. ROY : Diabetes, $14: 780,(1965)$. 53) 山田弘三, 他 : 日本内科学会雑誌, 52 : 1200, (1964). 54) ALP, H., LEGANT, L., KILO, C., EGGEMAN, J. and KOGH,M.B. : Diabetes, 13 : 509, (1964). 